\title{
Studies of the
}

\section{guild of ant-following birds at Belém, Brazil ${ }^{(*)}$}

\author{
YoshIKA ONIKI \\ Department of Biology, \\ Princeton University, Princeton, N. J .
}

\begin{abstract}
Studies of ant-following birds at Belém show that some species are professional ant-followers, that is, obtain more than $50 \%$ of their food near ants. Pro. fessional ant-followers at Belém are: Black-spotted Bare-Eye, Phlegopsis nigromaculata, White-backed Fire-Eye, Pyriglena leuconota, Scale-backed Antbird, Hylophylax poecllenota (Formicariidae); Barred Woodcreeper, Dendrocolaptes certhia, Plain-brown Woodcreeper, Dendrocincla fuliginosa, White-chinned Woodcreeper, D. merula; and Gray-headed Tanager Eucometis penicillata. A list of thirty-seven species of nonprofessional birds was obtained during the study period. Nonprofessional species only occasionally follow army ant raids. The army ant (Eciion hurchelli) was the main species followed. Foraging habits, perch heights and prey items were noted for most of the professional and nonprofessional species of birds. Also, their interactions at swarms of ants and a comparison with other ant-following guilds is provided.
\end{abstract}

\section{INTRODUCTION}

In tropical forests, as swarming carnivorous army ants approach, small animals run or fly helter-skelter. Birds flock around these swarms to obtain arthropods flushed by the ants. Some birds are so persistent at feeding near the ants that they have been termed "professional" antfollowers, that is, they obtain more than $50 \%$ of their food near the ants (Willis, 1967). Other species of birds form part of the avian antfollowing groups or "guilds" (Root, 1967) only now and then, and constitute the "nonprofessional" or "amateur" ant-followers.

Recent studies of ant-following birds show that different species follow ant raids in different regions. Chapin (1932) reports thrushes as the principal birds following driver ants in the
Belgian Congo. In the New World tropics, birds of the family Formicariidae (antbirds) are the main ant-followers. Skutch (1969) and Slud (1960, 1964) note ant-following birds in Costa Rica. Johnson (1954) briefly reports on antfollowing birds on Barro Colorado Island, Panamá Canal Zone. In a long-term study, Willis (1967) considers one of the main species in detail. He also reports in less detail on other species and on ant-followers in other Neotropica! legions (Willis, 1960, 1966a, 1966b, 1968a, 1968b. 1969). Oniki and Willis (in press) discuss antfollowing birds of the Guianas and nearby regions.

Meerwarth (1904) reports that in Pará, Brazil, Pyriglena atra (= Pyriglena leuconota) and Phlogopsis nigromaculata ( $=$ Phlegopsis nigromaculata) follow army ants constantly to feed on insects flushed by the ants. There have been no other studies of ant-following birds in that region. This report discusses observations of ant-following birds at Belém, Pará, Brazil.

\section{STUDY AREAS}

The study was conducted mostly at the Aurá Reserve (Novaes, 1970); occasional observations were made at the Mocambo Forest Reserve. These reserves are part of the APEG (Area de Pesquisas Ecológicas do Guamá) of the Instituto de Pesquisas e Experimentação Agropecuárias do Norte (IPEAN) at Belém.

The average rainfall of Belém (altitude $13 \mathrm{~m}$ : 1c 28' S lat., $48^{\circ} 27^{\prime} \mathrm{W}$ long.) from 1923 to 1963 is shown in Figure 1. The dry season is June to November.

(1) - Based on M. S. thesis, University of Kansas, U.S.A. 


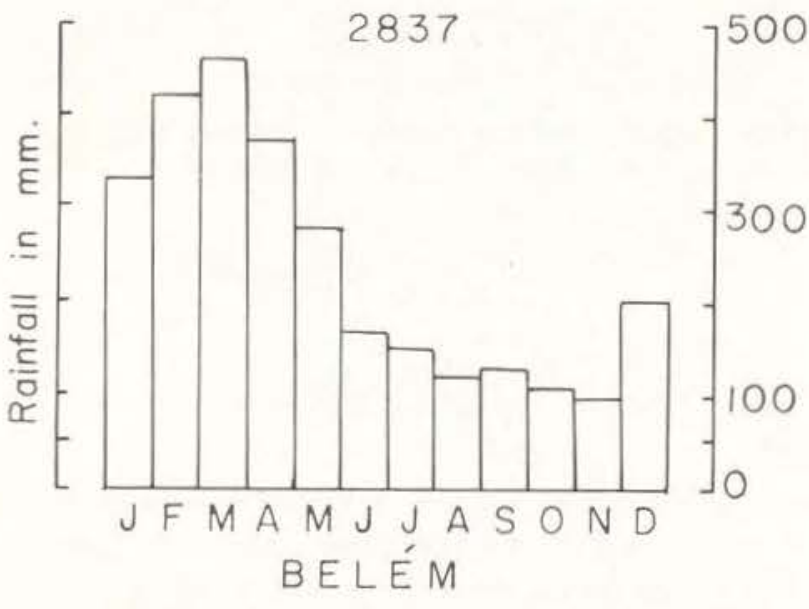

FIGURE 1 - Average montly and yearly rainfall at Belém in $\mathrm{mm}$.

The Aurá Reserve vegetation consists mainly of "várzea" or tidal-swamp forest, with a small plot of "terra-firme" forest or mature upland forest and a strip of "capoeira" or second growth bordering a small plantation of rubber trees. Dr. João Murça Pires, botanist at IPEAN, has studied in detail the ecology and composition of these forests.

The terra-firme forest is characterized by tall trees, some of them over $40 \mathrm{~m}$ high. They are slender and branch into a dense canopy. The leaves of these trees fall and decompose rapidly on the humid surface of the ground. Many bromeliads and mosses cover the tree trunks. Leguminous trees are the most important species in this type of forest. Very often the shallow-rooted trees fall before a storm or strong wind, opening clearings in the forest; shortly saplings develop there, replacing the old fallen trees. According to Kuhlmann (1959), Bertholletia excelsa (castanheira) and Castilloa ulei (caucho) are characteristic of terra-firme forest.

Várzea or swamp forests occur in areas regularly flooded by tides, which keep the ground wet and swampy. The tree species mostly differ from those of the terra-firme forest. Hevea brasiliensis (seringueira) and Calycophyllum spruceanum (pau mulato) cons. titute the highest trees $(40 \mathrm{~m})$ and other genera such as Sapium, Virola, Cordia, Inga, Reedia, Triplaris, Cecropia, Cassia, Plumeria, etc. cons. titute a lower stratum ( 20 to $30 \mathrm{~m}$ ). In an even lower stratum plants of the families Rubiaceae, Solanaceae, Myrtaceae, Sterculiaceae, Caricaceae, etc. are dominant (Kuhlman, 1959). However, várzea forest is poorer in species than terra-firme forest (Ducke and Black, 1954)

Capoeira or second-growth forest is characterized by low vegetation that grows up after the primary or virgin forest is cut. Grasses and sedges are abundant in the capoeira. Saplings, bushes and vines make the capoeira very thick and difficult to penetrate.

The Mocambo Forest Reserve is a terrafirme forest of 5.5 hectares surrounded by igapó forest and composed of dense and varied vegetation dominated by Calophyllum brasiliensis, Macrolobium, acaciefolium, Nectandra amazonum, Piranhea trifoliata, Triplaris surinamensis, Bombax aquaticum, etc. (Kuhlmann, 1959). The igapó forest is a forest of swampy areas permanently covered by water and differs from the várzea forest by the absence of such indicator plants as Euterpe oleracea.

\section{MATERIAL AND METHODS}

I studied ant-following birds by direct observation, using $7 \times 35$ binoculars. Identification of birds, using the nomenclature of Meyer de Schauensee (1966) was facilitated by the use of study skins of the Museu Paraense "Emilio Goeldi", Belém.

Part of the Aurá and all of the Mocambo reserve are marked in a grid of $10 \mathrm{~m}$ squares. with numbered tags on stakes at corners and with paths along major grid lines; this facilitated mapping movements of army ants and antfollowing birds.

From April 1966 to April 1968, I followed several colonies of the army ant Eciton burchelli to study the ant-following birds. Observations of ant-followers were taken mostly in the morning when ants and birds were most active; I made few observations in the afternoon, from 12:00 to $18: 00$. Ant-following birds were netted in front of a swarm only after at least two hours of observation. Captured birds were colorbanded, measured, and weighed. 


\section{THE ARMY ANTS}

The army ants the "tauócas" or murupeteca" of the Brazilian Indians, are carnivorous and hunt through the forest in large swarms, called "correições" in Brazil. As a swarm advances over the ground, ants examine logs, holes in the ground, dead fallen leaves, etc.

Important species of army ants for birds at Belém are Eciton burchelli and E. rapax, especially the former. According to Schneirla (1957) and Rettenmeyer (1963), Eciton burchelli has a life cycle with two distinct phases. In the "nomadic" phase, the ants raid actively all day to provide food for their growing larvae, and move the "bivouac" or temporary nest to another site almost every night. The bivouac movement is usually in the direction of the strongest branch of the swarm during the day. unless ants swarmed in one direction in the morning and changed to another direction in the afternoon. The distances between consecutive nomadic bivouacs at Belém averaged $70.1 \mathrm{~m}(n=274)$. The average length of the nomadic phase was 12.6 days $(n=8)$. In Panamá the length of the nomadic phase averages 13-14 days (Johnson, 1954; Willis, 1967) .

In the other or "statary" phase, the colony stays in one bivouac for about three weeks. In this phase, the queen lays eggs and the young of the previous brood are pupae. Few swarms occur in this phase, and on some days there are no raids. The bivouac is in a wellprotected place, such as under logs, inside a hollow trunk, or among tangled bushes. The average distance between consecutive statary bivouacs at Belém was $378.5 \mathrm{~m}(n=2)$. The statary phase at Belém averaged 19.6 days $(n=15)$, while in Panamá Willis (1967) found an average of 21.4 days.

\section{DESCRIPTIONS OF BIRD-ANT INTERACTIONS}

Before analyzing the activities of birds over ants in detail, it is helpful to have in mind descriptive pictures of the activities as one actually observes them in the field. The diverse types of interactions one can observe are best represented by two accounts, one of a nomadic day when ants are very active and one on a statary day when ants are not swarming from their bivouac at all.

A Nomadic Day: 1 arrive at the bivouac in a patch of second-growth forest at 06:50. At 07:18 a male White-backed Fire-Eye (Pyriglena leuconota) arrives. Perching on low twigs and hopping from one twig to another, he investigates the colony. He wanders about for a while as the ants start swarming; as soon as the ants spread out and start flushing insects he starts dropping down for them.

Gradually the number of birds increases, with female and other male Fire-Eyes calling and sallying to the ground or low branches for prey over the advancing swarm front. Grunting sounds from Black-spotted Bare-Eyes (Phlegopsis nigromaculata) indicate that they have arrived silently and are hiding behind low bushes. Plain-brown Woodcreepers (Dendrocincla fuliginosa) move in and fly from one trunk to another as they forage. The three main professional ant-followers are thus the first three species to arrive this morning.

A Long-billed Gnatwren (Ramphocaenus melanurus), foraging $4 \mathrm{~m}$ up, flutters rapidly from one perch to another and calls "tch-tchtch" as it wags its thin, long tail like the pendulum of a clock. Individual Silver-beaked Tanagers (Ramphocelus carbo) wander about, calling. A Moustached Wren (Thryothorus genibarbis) sings loudly, and its mate answers not far from the swarm. Now and then there are loud rapid calls or flutters of wings as one bird supplants another, mostly the three main antfollowers. Following chases, birds move apart and resume foraging as if nothing had happened.

Gradually some ant-followers leave the swarm, and new birds appear. A Gray-headed Tanager (Eucometis penicillata) forages near the ground, and rapidly flies to perch on a palm leaf and call excitedly.

As the swarm progresses, many ants carry pieces of prey back to the bivouac. Other ants still leave the bivouac for the front of the swarm. Foraging birds are still active, and most of the professional ones remain near the ants all day.

The swarm slowly decreases in the midafternoon as army ants start to move the 
bivouac to a new site. In the late afternoon the remaining birds wander to the new site and leave the ants, calling loudly. On this occasion, Fire-Eyes and Plain-brown Woodcreepers were the last birds observed leaving the surroundings of the new bivouac.

A Statary Day: Hiding behind a dush about $5 \mathrm{~m}$ from a low and inactive statary bivouac in terra-firme forest from $07: 15$ to $11: 15$, I watch the arrivals and departures of several professional ant-followers, which generally leave after investigating the ants for a few minutes

About 07:15, a Plain-brown Woodcreeper is $4 \mathrm{~m}$ up and about $15 \mathrm{~m}$ from the bivouac. At 07:23, one female White-backed Fire-Eye is in the tangled branches of a bush near the bivouac, calling "po-po-po" very quietly like the popping of bubbles. She moves from the ground to about $3 \mathrm{~m}$ up on different twigs; ai $2 \mathrm{~m}$ up she is immobile for 15 seconds and calls, then slowly hops and flutters toward the bivouac.

At 07:32 a pair of White-backed Fire-Eyes is near the bivouac. The male follows the female after perching $30 \mathrm{~cm}$ up on a vertical sapling and eating something he has captured. At 07:38 the pair is still around the bivouac, calling quietly but not pounding the tail (when pounding, the tail is raised slowly and lowered rapidly). One pair wanders nearby at 08:12 and two pairs at 09:11; single birds are present at $19: 50,10: 10$ and 10:50.

One or more Plain-brown Woodcreepers are observed or heard at 07:50, 08:40, 09:00, 10:26 and $11: 15$, suggesting that woodcreepers revisit or stay near the colony all morning.

Although such birds as Glyporynchus spirurus, Pipra rubrocapilla, and Xiphorhynchus guttatus pass by, they do not come very close to the bivouac or investigate it. No nonprofessional species visits the inative bivouac.

\section{SPECIES OF ANT-FOLLOWING BIRDS AT BELÉM}

1 recorded 7 species of professional ant followers and 37 nonprofessional species at Belém in two years of study. These species and their foraging behaviors are listed below. The Rufous-vented Ground-Cuckoo (Neomorphus geoffroyi) has been recorded near Belém and should be the eighth professional ant-follower there, as it follows ants regularly elsewhere. However, I did not find it on my study area No migratory birds were at swarms there Similarly large numbers of nonprofessionals have been recorded in other regions studied (Johnson, 1954; Oniki and Willis, in press), and the longer one studies, the more species are added to the list of nonprofessionals.

Beebe and Beebe (1910) reported "Humming. birds that appeared from nowhere, dashed down to a tiny insect and vanished into space". At Belém, some abundant species of humming. birds came low over the raiding ants, examined me, peered underneath thin, low branches, and then flew away; but I never saw them obtaining food over ants. Once, for instance, a Reddish Hermit (Phaethornis ruber) examined the branches of Calathea selowii (Marantaceae) and flew away without perching or pecking food. On another occasion a Long-tailed Hermit (Phaethornis superciliosus) came to a swarm and after examining the surroundings, got nectar from red flowers of Markea coccinea (Solanaceae) at 4 and $5 \mathrm{~m}$ up and flew away. Perhaps hummingbirds are attracted by the chirping and chattering of the assemblage of ant-followers then examine the situation and leave, since they never stay longer than a few seconds. Hummingbirds and other species that did not get food flushed by ants are not counted in the lists below.

\section{PROFESSIONAL ANT FOLLOWERS}

\section{ANTBIRDS (Formicariidae)}

White-backed Fire-Eye, Pyriglena leuconota. - This medium-sized antbird (Table 1), commonly called "mãe de taóca" (or mother of army ants), or "papa-taócas" (or the army-ant eater), is the most numerous species at swarms at Belém. Once I observed 12-14 Fire-Eyes at a swarm. They are often the first birds to visit the bivouac early in the morning even when ants have not yet started swarming.

The Fire-Eyes hop or fly rapidly to horizontal, diagonal or vertical perches (Table 2) near the ground (Table 3). Subordinate birds or ones scared by the observer or other big animals frequently fly to and perch on higher branches, to about 9-10 $\mathrm{m}$ up. They use slender perches much of the time (Table 4). 
TABLE 1

Characteristics of Professional Ant-Followers at Belém

\begin{tabular}{|c|c|c|c|c|c|c|}
\hline Species & Weight $(\mathrm{g})$ & Bill (mm) & Habitat & Height & Centrality & Movement \\
\hline White-backed Fire-Eye & 31.3 & 16.5 & 3 & $1-3$ & $1-2$ & 3 \\
\hline Black spotted Bare-Eye & 40.7 & 20.1 & 2 & 1 & 1 & 1 \\
\hline Scale-backed Antbird & 17.2 & 18.2 & $1-2$ & $1-2$ & 3 & 2 \\
\hline Plain-brown Woodcreeper & 45.7 & 30.2 & 1 & 3 & 3 & 1 \\
\hline White-chinned Woodcreeper & 37.9 & 24.7 & 1 & 1 & 2 & 2 \\
\hline Barred Woodcreeper & 61.5 & 38.9 & $1-3$ & $3-4$ & 2 & 1 \\
\hline Gray-headed Tanager & 30.7 & 18.8 & 2 & $2-3$ & 3 & 3 \\
\hline
\end{tabular}

Habitat: commonest in 1, terra-firme forest, 2, várzea, 3, capoeira.

Height: mainly $1,0-1 \mathrm{~m}$ up, $2,2-3 \mathrm{~m}$ up, 3, 4-6 $\mathrm{m}$ up, $4,6+\mathrm{m}$ up.

Centrality: tends to forage 1, centrally, 2, intermediately, 3 , peripherally.

Movement: normally 1 , patient, 2, either patient or active, 3 , moves often

TABLE 2

Perch Angles

Species

PROFESSIONALS

White-backed Fire-Eye

Black-spotted Bare-Eye

Scale-backed Antbird

Plain-brown Woodcreeper

White-chinned Woodcreeper

Barred Woodcreeper

Gray-headed Tanager

\section{NONPROFESSIONALS}

Wedge-billed Woodcreeper

Buff-throated Woodcreeper

Spix's Woodcreeper

Amazonian Antshrike

Spot-winged Antshrike

White-flanked Antwren

Cinereous Antshrike

Other Antbirds (5 spp.)

Squirrel Cuckoo

Blue-crowned Motmot

White-fronted Nunbird

Bright-rumped Attila

White-bearded Manakin

Royal Flycatcher

Ochre-bellied Flycatcher

McConnell's Flycatcher

Cocoa Thrush

River Warbler

Pectoral Sparrow

Others (7 spp.)
Angle in Degress

\begin{tabular}{|c|c|c|c|c|c|c|c|}
\hline $0.20^{\circ}$ & $-40^{\circ}$ & $-60^{\circ}$ & $-80^{\circ}$ & $.100^{\circ}$ & $-120^{\circ}$ & $-140^{\circ}$ & TOTAL \\
\hline 429 & 82 & 134 & 106 & 298 & & & 1049 \\
\hline 135 & 27 & 52 & 29 & 162 & & & 405 \\
\hline 6 & & 2 & & 32 & & & 40 \\
\hline \multirow[t]{2}{*}{13} & 1 & 26 & 31 & 1527 & & 7 & 1605 \\
\hline & & & & 21 & & & 2 \\
\hline 1 & & 2 & 2 & 124 & & & 129 \\
\hline 85 & 9 & 13 & 13 & 14 & & & 132 \\
\hline
\end{tabular}

129
134

31

90

35

4

26

5

4

6

3

6

6

8

3

4

3

3

6

7

5

10 
Ordinarily, this Fire-Eye sallies to the ground for prey and eats it there or flies back with it to a branch. It beats large prey against the perch to break off pieces, then picks up the pieces from the ground after eating the main part. It also seeks prey from high branches above the swarm or hops vertically for prey hiding under leaves. When watching from a very low branch or stem, it can stretch the neck to peck prey from the ground without sallying for it.

Most prey of these and other ant-following birds are swallowed so quickly that identification is difficult, so that only large and obvious prey is listed herein. Arthropods eaten by Pyriglena leuconota are mainly grasshoppers, crickets, beetles, cockroaches, and spiders. One small reddish ant, not an army ant, was in the stomach of one bird collected. Willis (1967) reports that he never found army ants in the two stomach samples I collected; also; I never saw Pyriglenà leuconota eating army ants. "Papa-taócas" is thus incorrect. However, they may sometimes swallow army ants together with food stolen from them.

These birds dominate other common species of ant-followers except for Black-spotted BareEyes, which chase and supplant them frequently.

TABLE 3

Bird Heights

Species

Height in Meters

$$
\begin{array}{lllllllllllllllllllllll}
0.1 & 0.2 & 0.3 & 0.4 & 0.5 & 0.6 & 0.7 & 0.8 & 0.9 & 1.0 & 2 & 3 & 4 & 5 & 6 & 7 & 8 & 9 & 10 & 11 & 12 & 13 & 14
\end{array}
$$

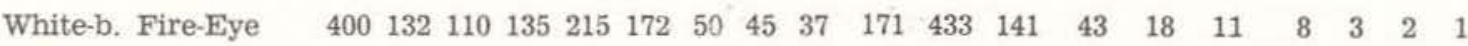

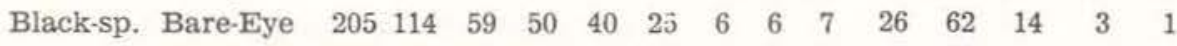

$\begin{array}{llllllllllll}\text { Scale-b. Antbird } & 12 & 2 & 1 & 3 & 9 & 7 & 4 & 5 & 2 & 5 & 13\end{array}$

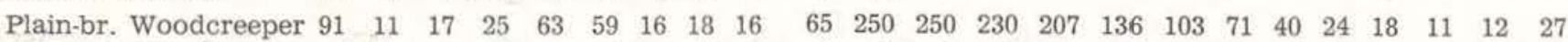

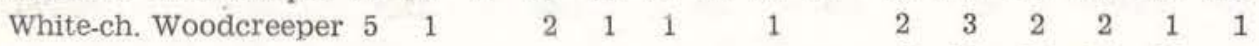

$\begin{array}{lllllllllllllllllllllll}\text { Barred Woodcreeper } & 4 & 1 & 1 & 2 & 4 & 3 & 2 & 2 & 5 & 23 & 26 & 24 & 13 & 8 & 7 & 8 & 5 & & 1 & 1 & 1\end{array}$

$\begin{array}{llllllllllllllllllllllll}\text { Gray-h. Tanager } & 11 & 3 & 2 & 2 & 3 & 1 & 2 & 2 & 11 & 50 & 63 & 43 & 42 & 30 & 22 & 12 & 7 & 5 & 3 & 1 & 1 & 1\end{array}$

Wedge-b. Woodcreeper

Buff-thr. Woodcreeper

Spix's Woodcreeper 2

Great Antshrike 3

White-sh. Antshrike 1

Amazonian Antshrike

Spot-w. Antshrike

$\begin{array}{lllllllll}\text { Plain-thr. Antwren } & 5 & 2 & 2 & 4 & 4 & 5 & 2 & 1\end{array}$

White-fl. Antwren

Cinereous Antshrike

Gray Antbird

Other Antbirds (3 spp.) $2 \quad 1 \quad 1 \quad 1 \quad 1$

Smooth-b. Ani

Blue-cr. Motmot

Red-h. Manakin

White-b. Manakin

Royal Flycatcher

Ochre-b. Flycatcher 1

McConnell's Flycatcher

Moustached Wren

Cocoa Thrush

Long-b. Gnatyren

River Warbler

Silver-b. Tanager

Pectoral Sparrow

Others (7 spp.)

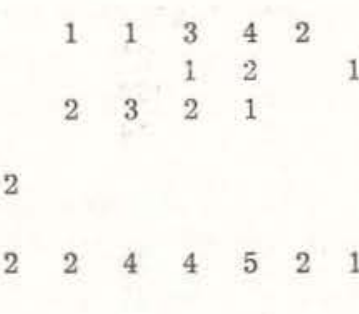

1

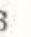

$\begin{array}{llllllllll}2 & 6 & 5 & 4 & 4 & 3 & 4 & 3 & 1 & 7\end{array}$

$\begin{array}{lllllllllllll}7 & 21 & 27 & 15 & 16 & 10 & 14 & 12 & 8 & 3 & 1 & 1 & \end{array}$

$\begin{array}{lllllllllll}4 & 11 & 6 & 7 & 4 & 2 & 4 & 2 & 2 & 1 & 1\end{array}$

$\begin{array}{llllll}1 & 2 & 3 & 4 & 1 & 1\end{array}$

$\begin{array}{lllllllllll}1 & & 3 & & & & & & & & \\ 1 & 4 & 3 & 3 & 7 & 5 & 3 & 1 & 1 & 1 & \end{array}$

$\begin{array}{llllllllll}1 & 4 & 3 & 3 & 7 & 5 & 3 & 1 & 1 & 1 \\ 1 & 3 & 4 & & & 1 & 1 & & 1\end{array}$

$\begin{array}{llllll}2 & 9 & 2 & 1 & 1 & 1\end{array}$

$\begin{array}{lllll}1 & 2 & 2 & 5 & 1\end{array}$

$\begin{array}{lllllll}2 & 2 & 2 & 2 & 1 & 2\end{array}$

$\begin{array}{llllllllll}1 & 2 & 2 & 3 & 3 & 2 & 1 & 4 & 2 & 2\end{array}$

$\begin{array}{lll}2 & 2 & 1\end{array}$

$\begin{array}{lll}3 & 2 & 1\end{array}$

$\begin{array}{rrrrrrrrrrrrr} & & & 1 & 4 & 2 & 4 & 1 & & & 1 & 1 & \\ 1 & 8 & 12 & 9 & 7 & 10 & 9 & 3 & 1 & 1 & & 1\end{array}$

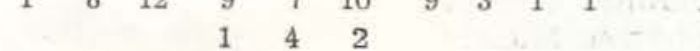

$\begin{array}{lllll}1 & 2 & 2 & & \\ 1 & 3 & 2 & 1 & 1\end{array}$

$\begin{array}{llllllll}2 & 2 & 2 & 1 & 1 & 1 & 2 & 1\end{array}$

$\begin{array}{lll}2 & 4 & 2\end{array}$

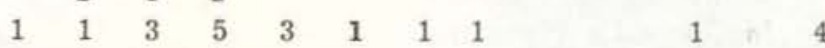

$\begin{array}{lllllllll} & 1 & & 1 & & & & & \\ 1 & 2 & 4 & 5 & 4 & 2 & 3 & 2 & 1\end{array}$

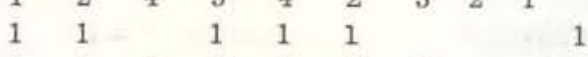

$\begin{array}{lllllll}1 & 1 & 4 & 5 & 1 & 2 & 1\end{array}$ 
Fire-Eyes are sometimes aggressive against individuals of other species, including larger ones. Once I observed one chase a Whitefronted Nunbird (Monasa morphoeus), three times its weight, that was feeding near the ground. The nunbird flew to a height of $4 \mathrm{~m}$; the White-backed Fire-Eye then perched not far from it.

The Fire-Eyes were most common in or near second-growth forest at Belem, but they followed army ants through patches of mature upland forest (terra-firme) or swamp forest (varzea) without strong habitat limitations. At times they perched on low twigs over ants in a grassy clearing, even though shyer antbirds like Black-spotted Bare-Eyes avoid clearings. One Fire-Eye banded in the Mocambo Reserve later was found in the Aurá swamp forest; it must have moved across roads and through oilpalm or rubber plantations. However, in swamp forest they are less numerous than the Blackspotted Bare-Eye. Near Santarém, Pará, FireEyes are most common in patchy forest and second growth and rare in extensive areas of forest (Willis, pers. comm.).

Black-spotted Bare-Eye, Phlegopsis nigromaculata. - This large antbird is also called "mãe de taóca" (or mother of the army ants), because local people believe that if you see it in the forest you are almost certain to see a

TABLE 4

Perch Diameters

Species

White-backed Fire-Eye Black-spotted Bare-Eye Scale-backed Antbird Plain-brown Woodcreeper White-chinned Woodcreeper Barred Woodcreeper Gray-headed Tanager Squirrel Cuckoo Blue-crowned Motmot White-fronted Nunbird Red-stained woodpecker Wedge-billed Woodcreeper Buff-throated Woodcreeper Spix's Woodcreeper White-shouldered Antshrike Spot-winged Antshrike Cinereous Antshrike Plain-throated Antwren Gray Antbira

Silvered Antbird Rufous-capped Antthrush Red-headed Manakin White-crowried Manakin White-bearded Manakin Royal Flycatcher Ochre-belliel Flycatcher McConnell's Flycatcher Cocoa Thrush

Whitemecked Thrush

River Warkbler

Pectoral Sparrow
TOTAL
Diameter in $\mathrm{cm}$.

\begin{tabular}{|c|c|c|c|c|c|c|c|c|c|c|c|}
\hline-1 & -2 & -3 & -4 & .5 & -10 & -15 & -20 & -25 & -50 & -160 & TOZAL \\
\hline 336 & 224 & 107 & 32 & 14 & 50 & 8 & 4 & & 4 & & 779 \\
\hline 109 & 95 & 39 & 18 & 8 & 29 & 8 & 3 & & & & 309 \\
\hline 23 & 4 & 1 & & & & & & & & & 28 \\
\hline \multirow[t]{2}{*}{7} & 49 & 85 & 85 & 50 & 350 & 201 & 68 & 34 & 36 & 1 & 966 \\
\hline & 3 & & & & 3 & 1 & 1 & & & & 8 \\
\hline 1 & & 4 & 4 & 4 & 55 & 25 & 19 & 5 & 8 & & 125 \\
\hline 79 & 21 & 2 & & 1 & 2 & 4 & & & & & 109 \\
\hline 1 & 1 & & & & & & & & & & 2 \\
\hline \multirow{4}{*}{$\begin{array}{l}1 \\
3\end{array}$} & 1 & 3 & & & 1 & & & & & & .j \\
\hline & & & & & & & & & & & 3 \\
\hline & & 1 & & & & & & & & & 1 \\
\hline & & 1 & 2 & 1 & 3 & 3 & 2 & 3 & 9 & & 24 \\
\hline \multirow[t]{2}{*}{2} & & 5 & 2 & 1 & 35 & 18 & 8 & 3 & 4 & 2 & 80 \\
\hline & 6 & 4 & 8 & 1 & 10 & 3 & 3 & & 4 & & 39 \\
\hline 1 & & & & & & & & & & & 1 \\
\hline 1 & & & & & & & & & & & 1 \\
\hline 2 & & & & & & & & & & & 2 \\
\hline 7 & 6 & & & 1 & 1 & & & & & & 15 \\
\hline \multirow[t]{3}{*}{2} & & & & & & & & & & & 2 \\
\hline & 1 & & & & & & & & & & 1 \\
\hline & 1 & & & & & & & & & & 1 \\
\hline 2 & 1 & & & & & & & & & & 3 \\
\hline \multirow[t]{2}{*}{1} & & & & & & & & & & & 1 \\
\hline & 1 & & & & & & & & & & 1 \\
\hline 2 & & & & & & & & & & & 2 \\
\hline 3 & & & & & & & & & & & 3 \\
\hline 3 & & & & & & & & & & & 3 \\
\hline \multirow[t]{2}{*}{2} & 2 & & & & 2 & & & & & & 6 \\
\hline & & 1 & & & 1 & & & & & & 2 \\
\hline 1 & 1 & 2 & 1 & 2 & & & & & & & 7 \\
\hline 1 & & & & & & 1 & 1 & & & & 3 \\
\hline 590 & 417 & 255 & 152 & 83 & 542 & 272 & 109 & 45 & 65 & 3 & 2533 \\
\hline
\end{tabular}


raid of army ants. I generally found Bare-Eyes only near active raids of ants, but on a few occasions one was at an inactive statary bivouac.

The Bare-Eye perches quietly at the front of a swarm and watches for prey for up to several minutes. Several times, I saw one standing on the ground in the middle of the ants, but soon it flew back to a vertical or horizontal branch as the ants started climbing and biting its legs.

Bare-Eyes feed on arthropods, especially grasshoppers, cockroaches, crickets, beetles and spiders. When a Bare-Eye spots prey, it hops to the ground in the midst of ants. Another way Phlegopsis nigromaculata captures prey is to perch near the ground and reach the food by lunging.

Now and then the seeming harmony of birds over army ants is interrupted by strong fluttering sounds and loud calls from several birds. Often the domineering Black-spotted Bare-Eye is supplanting and chasing other birds, and usurping the best foraging places over the ants. White-backed Fire-Eyes, Plain-brown Woodcreepers, and sometimes Gray-headed Tanagers are the other species frequently supplanted.

Phlegopsis nigromaculata is most common in swamp forest, but follows army ants without habitat limitations. In second growth it is less common than is Pyriglena leuconota.

Scale-backed Antbird, Hylophylax poecilonota. - This small antbird was usually in swamp (várzea) and mature upland (terra firme) forest, seldom in second-growth (capoeira). It perches for long periods (10-105 seconds) on low, thin vertical branches from the ground to $2 \mathrm{~m}$ up

When following army ant swarms, it obtains much food on the ground, by sallying down or by searching and pecking under fallen leaves It also searches and pecks under low green leaves or reaches prey by stretching down from its perch.

Usually only one bird was at a swarm of ants. Wher a pair was present, they often wandered separately. As the species is low on the interspecific peck order, it may be difficult for both birds to find places to forage close together. Wandering about may be the best way to find places unoccupied by larges antbirds.

\section{WOODCREEPERS (Dendrocolaptidae)}

Plain-brown Woodcreeper, Dendrocincla fuliginosa. - Many members of the family Dendrocolaptidae, including this medium-sized bird, are called "arapaçú" in Brazil. This woodcreeper commonly follows ants at Belém, where I have seen up to 7 birds at a swarm, but occasionally occurs alone or with wandering flocks.

When attending swarms, the Plain-brown Woodcreeper perches on a vertical trunk, from the ground to $25 \mathrm{~m}$ up, and looks about for prey for some seconds or minutes. It often perches below $7 \mathrm{~m}$ when attending swarms, but when far from ants it forages and flies higher. When one sees prey it flies after it and/or hitches up the trunk to reach it. When dominant species are not around, this woodcreeper may perch near the ground and sally clumsily and noisily into the middle of the ants for prey, then return to the same or a closer trunk to swallow the prey. Also, the bird may fly from a trunk, hover momentarily under higher leaves for a hiding insect, and return with it or fly to a closer trunk. Plain-brown Woodcreepers forage at the edges of the swarm and also behind the main activity areas of the dominant antbirds.

Foods taken are mainly spiders, centipedes, beetles, grasshoppers, crickets, cockroaches and relatively large black ants. I have not seen them take army ants. Large prey is beaten against the trunk as the bird moves the prey along the beak until it can be swallowed. Between attempts at swallowing, the bird may climb the trunk gradually; sometimes it approaches the top of the trunk, then flies with a big fragment of food still in the beak.

At Belém, Dendrocincla fuliginosa is most common in terra-firme forest, but it follows army ants through other kinds of forest without habitat limitations.

White-chinned Woodcreeper, Dendrocincla merula. - This medium-sized bird was mainly in mature terra-firme forest and at the limits of second-growth vegetation, where it climbed or watched from vertical medium-sized trunks from 
0.2 to $6 \mathrm{~m}$ up. It seldom comes out to trail clearings, but does so momentarily if there is prey. White-chinned Woodcreepers seemed quite uncommon at the Aurá Reserve; they were mostly observerd at the Mocambo Forest.

A White-chinned Woodcreeper obtains most of its food on the ground, to which it flies quickly but clumsily to catch big cockroaches or grasshoppers. It does not stay perched for a long time, and moves rapidly from one trunk to another. Once one supplanted a male White-backed Fire-Eye over army ants. These antbirds seem uneasy when a White-chinned Woodcreeper is close by; they peck food rapidly and flee. Once a male White-backed Fire-Eye unsuccessfully tried for prey on the ground and flew away, and immediately afterward a Dendrocincla merula captured a large prey item there.

Barred Woodcreeper, Dendrocolaptes certhia. - Like the smaller Plain-brown Woodcreeper, this large woodcreeper sometimes forages near the ground as well as climbing vertical tree trunks. Unlike Plain-brown Woodcreepers, they also hitch down trunks for prey. When perched looking for food, they wait from about 10 to 135 seconds. They obtain most of their food by sallying to the air or to trunks or dead dried palm leaves, enroute from one perch to another. Sometimes one returns to the same trunk after capturing an arthropod. Often one hits prey against the trunk to smash it before swallowing; at times the bird hitches slowly up the trunk as it prepares the prey. The only prey identified was a large grasshopper.

Barred Woodcreepers chased Plain-brown Woodcreepers three times over ants, but one was chased once by a Buff-throated Woodcreeper.

\section{TANAGERS (Thraupidae)}

Gray-headed Tanager, Eucometis penicillata. - I observed these medium-sized birds mostly in swamp or várzea forest, although they sometimes followed army ants in capoeira or second growth. I never observed them in the Mocambo Forest.

At ant swarms, they usually perch on horizontal, thin branches between 1 to $8 \mathrm{~m}$ up and dive rapidly to near or on the ground for prey whenever dominant antbirds are not about. Frequently a tanager perches on horizontal palm leaves and in flights to other perches tries for flying insects or ones under leaves or hanging bromeliads. Also, it can hop vertically along a branch and try for prey above its head. Food is mainly such insects as grasshoppers and cockroaches, up to one or two times the length of the beak.

The Gray-headed Tanager usually forages at the periphery of a swarm and seldom comes to the central, best places. When dominant birds are nearby it often flies to another twig over the swarm. At swarms of ants, Eucometis penicillata looks about very actively, flits the tail and wings rapidly and periodically erects the crest, and flies often to perch on different branches; it thus avoids encounters with dominant birds. Although Gray-headed Tanagers sometimes attacked or resisted Plain-brown Woodcreepers, they were subordinate in attacks by Buff-throated Woodcreepers, Black-spotted Bare-Eyes, and White-backed Fire-Eyes.

The Gray-headed Tanager regularly joins interspecific social flocks (Oniki, 1971) and wanders through the forest with other species of birds. In Panamá they seldom join flocks; they are much less tame than ar Belém and more often depart for other colonies of ants when the observer arrives (E. Willis, pers. comm.). Perhaps they do not do so at Belém because they are more common and encounter humans more often, or because they cannot depend on swarms of army ants for food at Belém because of competition from other species of birds.

\section{NONPROFESSIONAL ANT-FOLLOWERS}

\section{FALCONS (Falconidae)}

Lined Forest-falcon, Micrastur gilvicollis. Once I observed one perched on a horizontal branch $2.5 \mathrm{~m}$ up at the edge of tidal swamp forest. It may have been chasing the antfollowing birds or following army ants. Once one scared some birds following a column of ants in second growth. Oniki and Willis (in press) found forest-falcons following ants for insect prey in Guyana. 
cuckoos (Cuculidae)

Squirrel Cuckoo, Piaya cayana. - This bird occasionaily follows ants in second-growth, from the ground to $8 \mathrm{~m}$ up. It perches mostly on horizontal branches and flies short distances to the ground or to other branches for prey. At times it gives a loud "chicuã", which is its local name.

Smooth-billed Ani, Crotophaga ani - Once I observed one following army ants in thick, tangled second-growth vegetation. It perched for a long time about 1.5 to $4 \mathrm{~m}$ up, and pecked at insects now and then. Beebe and Beebe (1910) also record Smooth-billed Anis following army-ant raids in Guyana.

\section{MOTMOTS (Momotidae)}

Blue-crowned Motmot, Momotus momota. - Possibly one individual, judging by its aluminum band and distinctive tail feathers, followed ants in second-growth and at the edge of swamp forest on 20 October and 24 November 1967 and on 16 March 1968. It perched on horizontal thin branches from the ground to about $15 \mathrm{~m}$ up. Occasionally it obtained food on the ground.

\section{PUFFBIRDS (Bucconidae)}

White-fronted Nunbird, Monasa morphoeus. - This large nunbird, named "bico de brasa" or "tamburi-pará" by local people, alone or in pairs follow army ants whenever the ants pass through second-growth. Perched most of the time on high horizontal thin branches, it looks about for a long time, then sallies out to capture flying prey. When perching, it seems to gain equilibrium by holding the tail downward.

\section{TOUCANS (Ramphastidae)}

Channel-billed Toucan, (Rampastos vitellinus. - On three occasions individuals of this species came as low as $4 \mathrm{~m}$ over the swarm. but they soon flew off when they noticed me. E. Willis (peus. comm.) has seen closely related species of toucans following army ants in Panamá and Colombia. Normally they are so timid that they fly away when they see an observer.
WOODPECKERS (Picidae)

Red-stained Woodpecker, Veniliornis affinis. - On 13 September 1966, one bird stayed around the ant-following birds between 09:21 and $12: 20$, but foraged by pecying at tree trunks. Perhaps it was attracted by the birds rather than by the ants, since it often follows forest flocks away from ants (Oniki, 1971).

\section{WOODCREEPERS (Dendrocolaptidae)}

Wedge-billed Woodcreeper, Glyphorhynchus spirurus. - This small woodcreeper circled ant swarms occasionally, but always stayed on the periphery. Alone, in pairs, or in families, it perches on thick vertical trunks from 1 to $15 \mathrm{~m}$ up and climbs rapidly, pecking here and there.

Buff-throated Woodcreeper, Xiphorhynchus guttatus. - This large bird was frequently alone at swarms in tidal swamp and mature upland forest. It perches mostly on vertical trunks of trees from 1 to $80 \mathrm{~cm}$ in diameter and at heights from 0.5 to $20 \mathrm{~m}$. When climbing a trunk, it hitches up rapidly with slight movements of the neck and head; then it stops and looks about for prey. Frequently it perches on the under sides of diagonal branches or hangs at an angle under dead leaves. Although its stays with other ant-following birds, the Buff-throated Woodcreeper looks for food underneath bark, curled palm leaves or dead Cecropia leaves, in holes in trunks, and in Camponotus (tracuá ants) nests. At such times the bird is noisy, pecking and searching for prey with its strong beak. It chases Barred Woodcreepers and Spix's Woodcreepers now and then.

Spix's Woodcreeper, Xiphorhynchus spixii. - This bird was in tidal swamp, mature upland, and second-growth forests. It stays near antfollowing birds, sometimes for several hours. Perching mainly on vertical medium-sized trunks, it obtains food on the trunks or in cavities into which it snakes its head to peck hidden arthropods. When foraging, it moves about rapidly from one trunk to another but sometimes flies to the ground to get an insect. Also, it searches for food in hanging dead palm leaves and rotten trunks, sometimes perching underneath them.

When one follows army ants, Buff-throated and Barred Woodcreepers supplant and chase it. 
OVENBIRDS (Furnariidae)

Plain Xenops, Xenops minutus. - One was observed and netted feeding over army ants in swamp forest. It normally perches on thin horizontal or vertical branches from 4 to $6 \mathrm{~m}$ up as it participates in wandering flocks.

\section{ANTBIRDS (Formicariidae)}

Great Antshrike, Taraba major. - A pair of these large antbirds followed ants for two days in October, 1966, in very thick, tangled secondgrowth. Most of the time they perched on horizontal branches from the ground to $7 \mathrm{~m}$ up. They obtained food on the grou d, on twigs, and in flight. They were very shy and did not stop long at a perch. Once the male antshrike chased a male Fire-Eye.

White-shouldered Antshrike, Thamnophilus aethiops. - This is a bird that participate in wandering flocks and joins ant-following birds now and then. Once one was chased by a leafscraper (Sclerurus sp.) at a height of $2.5 \mathrm{~m}$. It forages from the ground to $3 \mathrm{~m}$ up. One obtained a caterpillar $1.5 \mathrm{~cm}$ long under leaves $3 \mathrm{~m}$ up.

Amazonian Antshrike, Thamnophilus amazonicus. - Alone or in pairs, these antshrikes were occasionally over ants in second-growth, vegetation near várzea. They hop rapidly between horizontal or vertical branches from 0.2 to $12 \mathrm{~m}$ up.

Spot-winged Antshrike, Pygiptila stellaris - This bird usually associates with wandering flocks, but when a flock meets ant-following birds at a swarm all associate for a while; soon both flocks part, each following its own course (Oniki, 1971). Over ants, these antshrikes forage rapidly through the lower canopy from 1.6 to $8 \mathrm{~m}$ up, using thin horizontal or diagonal perches, and stretch to reach prey under leaves or inside curled dried leaves.

Plain-throated Antwren, Myrmotheiula hauxwelli. - Alone or in pairs, this small, shorttailed bird follows swarms occasionally. It also follows wandering flocks. It perches on horizontal, diagonal, or vertical thin twigs, mostly near the ground, and wanders from one branch of a swarm to another as it searches for food
It usually is at the periphery of a swarm rather than in the center. When perched on a twig, it often flits the wings strongly and seems nervous as it changes perches on vertical stems. It gets food on the ground or under low leaves or twigs, often by stretching out to reach the prey.

White-flanked Antwren, Myrmotherula axillaris. - This tiny antbird associates with wandering flocks. When birds of a wandering flock join ant-following birds (Oniki, 1971). $M$. axillaris sometimes obtains food by fluttering about actively from 2.5 to $4 \mathrm{~m}$ up on horizontal. diagonal, and vertical thin branches.

Cinereous Antshrike, Thamnomanes caesius. - These antbirds sometimes join ant-following birds when a wandering flock passes an ant swarm. From thin horizontal, diagonal, or vertical branches from the ground to $4 \mathrm{~m}$ up, they sally out to catch flying insects and alight on new perches.

Gray Antbird, Cercomacra cinerascens. This antbird is usually found at the edges of mature forest and second-growth, seldom at the edges of tidal swamp forest. None was observed in the Mocambo Reserve. It perches and feeds on high branches under the canopy or in suspended tangles of lianas. It moves rapidly through the tangles, which makes it difficult to study.

I saw a pair following army ants onlk once, in September 1966, in second-growth. They then perched low, from 3-6 m up, and picked up insects under leaves or on branches as they moved rapidly through thick vegetation.

Silvered Antbird, Sclateria naevia. - One was observed and captured in a mist net set ahead of a swarm in the swamp forest. It perches low, about 20 to $30 \mathrm{~cm}$ up, on thin diagonal branches.

Rufous-capped Antthrush, Formicarius colma. - This bird followed army ants occasionally. usually walking on the ground but sometimes hopping up to thin horizontal or diagonal branches 0.4-0.5 $\mathrm{m}$ above the ground.

Black-faced Antthrush, Formicarius analis - Occasionally this large antthrush follows swarms, "pounding" the tail while walking and foraging on the ground around the ant raid. 


\section{COTINGAS (Cotingidae)}

Bright-rumped Attila, Attila spadiceus. On 1 September 1967, I observed individuals of this species foraging at heights of 3 and $4 \mathrm{~m}$ over ants in mature swamp forest.

\section{Manakins (Pipridae)}

Red-headed Manakin, Pipra rubrocapilla. This is a very common bird at the edges of second-growth and swamp forests. When army ants passed such areas one or a few sometimes followed the raid for several minutes. They flew from one thin branch to another about 3 to $10 \mathrm{~m}$ up and caught food on the way. At times other ant-followers, such as Plain-brown Woodcreepers, chase one.

White-crowned Manakin, Pipra pipra This little manakin stays at the periphery of ant swarms most of the time rather than over the swarm center. It perches about 4 or $5 \mathrm{~m}$ up on thin horizontal or diagonal branches. Usually it stays for a while looking about, then flies for prey.

White-bearded Manakin, Manacus manacus. - This small manakin lives in second growth. Usually it is not interested in army ant swarms, since it feeds primarily on the dark violet fruits of the Melastomataceae (Snow, 1962). However, one or more occasionally follow an army ant swarm for as long as several hours, feeding on small insects snapped from the air or branches in flights between branches. These birds are very fast in flight; when foraging they continually move from one twig to another. The White-bearded Manakin usually stays at the fringes of the swarm or at its side branches and seldom goes to the best places where antbirds get food.

\section{TYRANT-FLYCATCHERS (Tyrannidae)}

Great Kiskadee, Pitangus sulphuratus. Once when army ants were swarming at the edge of second growth, a Kiskadee flew down to a perch $1.5 \mathrm{~m}$ up and then toward the ground. Perhaps it was capturing prey flushed by the ants.
Royal Flycatcher, Onychorhynchus coronatus - Occasionally this bird follows army ants at the edges of mature upland forest. A few were mist-netted in front of swarms. They perch on thin horizontal branches from 4 to $6 \mathrm{~m}$ up and obtained food in flight from one branch to another. One beat a large grasshopper against a limb for a time before swallowing it.

Ochre-bellied Flycatcher, Pipromorpha oleaginea. - Only one bird was observed at a swarm, at the borders between mature forest and second-growth. It stayed at the periphery of the swarm most of the time, perching on thin horizontal branches from 0.1 to $4 \mathrm{~m}$ up. This individual called "pi-pi" and once sang a series of "ptui-pi" notes repeatedly for a long time at an average of eight series per minute.

McConnell's Flycatcher. Pipromorpha macconnelli. - This bird follows ants only when they pass through areas where it regularly occurs, just inside the borders of mature forest. On 17 February 1968 and 7 March 1968, a previously banded bird followed swarms of Eciton burchelli for one hour at the same place in the forest. I captured it in a mist net and checked its plumage and band number for identification on 17 February. Perching on thin, horizontal or diagonal twigs from $1.5 \mathrm{~m}$ to $6 \mathrm{~m}$ up, it obtained small insects by flying rapidly from one twig to another. Some of the flights were 2.5 to $3.0 \mathrm{~m}$ long. Usually the bird was at the periphery of the swarm and not at the center. When following army ants, it opened the beak widely to call "pru-pru-pru-pru-pru" at frequent intervals.

\section{WRENS (Troglodytidae)}

Moustached Wren, Thryothorus genibardis. - This large wren is usually in pairs or in thick second growth. Whenever ariny ants swarm nearby, they follow the swarm for a while, hop busily from one branch to another and move their heads and tails rapidly. They perch on thin horizontal, diagonal or vertical branches from 1 to $10 \mathrm{~m}$ up. They obtain food on the branches or peck under dried leaves. 
THRUSHES (Turdidae)

Cocoa Thrush, Turdus fumigatus. - This thrush is usually in swamp forest, where it occasionally follows army ants. It forages low, standing from the ground to $4 \mathrm{~m}$ up on mediumsized horizontal or diagonal branches. In Trinidad, it commonly follows army ants in cacao plantations (Willis, 1966b).

White-necked Thrush, Turdus albicollis. Some of these birds were occasionally at swarms at the edges of swamp forest. They hop on the ground or perch on horizontal medium-sized branches from 1 to $3 \mathrm{~m}$ up.

\section{WARBLERS (Sylviidae)}

Long-billed Gnatwren, Ramphocaenus melanurus. - This little bird is usually in second- growth or at the edges of mature forest, where tangled, thin twigs are abundant. Several times single birds or pairs were observed near a swarm of ants, but on only a few occasions did they seem really interested and follow the army ants. At such times they busily moved from one branch to another. At times, between calls, one stopped to pick up an insect or two on the trunk or on a branch, spread the tail after eating, closed the tail and resumed its path through the undergrowth.

Usually they perch fairly high, between 4-15 m up. On only three occasions, when following army ants, were they much lower, about $50 \mathrm{~cm}$ up. However, White-backed FireEyes chased them and they soon flew up into the undergrowth.

\section{WOOD-WARBLERS (Parulidae)}

River Warbler, Basileuterus rivularis. This bird occasionally follows ants in swamp forest. It hops actively between horizontal or diagonal thin perches on the ground or to $4 \mathrm{~m}$ up. It makes constant sideward and downward movements with the widespread tail. Also it makes short leaps in the air to catch insects and, after eating, wipes the bill on its perch.

\section{TANAGERS (Thraupidae)}

Silver-beaked Tanager, Ramphocelus carbo. - Alone or in pairs, this inhabitant of second- growth and open areas follows army ant raids whenever they cross second growth. The bird sometimes is in a wandering flock and joins an ant-following group for some time when the two groups meet.

It perches mostly on horizontal and diagonal twigs from the ground to $8 \mathrm{~m}$ up and looks for food on branches or underneath leaves.

Once one female was chased away by a Plain-brown Woodcreeper.

\section{FINCHES (Fringillidae)}

Pectoral Sparrow, Arremon taciturnus. Alone or in pairs, these birds follow ant swarms irregularly, mostly in swamp forest. They perch low, near the ground or up to $6 \mathrm{~m}$, on horizontal or diagonal thin branches, and forage very actively with slight movements of the wings and tail.

\section{NUMBERS OF BIRDS AT SWARMS}

Table 5 lists the average numbers of birds attending swarms of Eciton burchelli at Belém. "Number attending a swarm" is the total number of individuals (professional and nonprofessional) recorded during an observation period of several hours. Fewer birds were present at any one time, since some birds (especially nonprofessional ones) visited only briefly. The numbers are approximate and in general underestimated, since some birds were very timid and not counted and others such as White-backed Fire-Eyes were too abundant to be accurately counted. However, this list will give an idea of the relative numbers of birds.

The White-backed Fire-Eye is the most abundant ant-follower; the Black-spotted BareEye and the Plain-brown Woodcreeper are, respectively, the second and third most abundant species.

There are usually more birds at nomadic raids than at statary raids. Fifty-six nomadic raids averaged 12.9 birds each, while 34 statary raids averaged 9.3 birds each.

\section{HABITATS AND BIRD SPECIES}

Table 6 shows the average numbers of birds per swarm in different habitats at Belém Observations taken in terra-firme at Aurá Re- 
serve were considered as second-growth, since there is only a very small area of terra-firme between swamp forest and second-growth there. I considered birds observed at Mocambo Forest Reserve under terra-firme even though this habitat occupies a rather small area surrounded by igapó forest.

Professional ant-followers follow army ants in all or nearly all types of forest. When an army ant swarm moves from one type of habitat to another, the professional birds usually stay with the ants. However, some professional species are more common in capoeira and others in swamp or upland forest. White-backed Fire-Eyes are more common in second-growth while Black-spotted Bare-Eyes are more common in swamp forest. The uncommon Scale-backed Antbird, White-chinned, and Barred Woodcreepers were recorded more frequently in mature habitats, particularly terra-firme. Plain-brown Woodcreepers were most common in the Aurá Reserve, in both second-growth and swamp forest. Gray-headed Tanagers were found only in the Aurá Reserve, and were mainly in swamp forest.

Nonprofessionals, which have other sources of food, follow the ant raids occasionally for short periods of time when ants happen to cross their territories or habitats. Of the 17 species of nonprofessionals recorded at Belém, 17

TABLE 5

Numbers of Birds at Swarms

Species
Professionals
White-backed Fire-Eye
Black-spotted Bare-Eye
Scale-backed Antbird
Plain-brown Woodcreeper
White-chinned Woodcreeper
Barred Woodcreeper
Gray-headed Tanager
Nonprofessionals (37 spp.)
T O T A L

Average Number of Birds Per Swarm
Total no of birds at 153 Swarms

$\begin{array}{r}9.53 \\ 4.78 \\ 1.77 \\ 031 \\ 1.98 \\ 0.05 \\ 0.22 \\ 0.42 \\ 2.84 \\ \hline 12.37\end{array}$

$\begin{array}{r}1459 \\ 732 \\ 271 \\ 47 \\ 303 \\ 8 \\ 34 \\ 64 \\ 434 \\ \hline 1893\end{array}$

No. Of Swarms at which the sp. was present
153

141

115

36

124

8

29

38

118

TABLE 6

Average Numbers of Birds Per Swarm in Different Habitats

Species

Professionals
White-backed Fire-Eye
Black-spotted Bare-Eye
Scale-backed Antbird
Plain-brown Woodcreeper
White-chinned Woodcreeper
Barred Woodcreeper
Gray-headed Tanager
Nonprofessionals
T O T A L

\section{Habitat}

\begin{tabular}{c}
$\begin{array}{r}\text { Várzea } \\
(\mathbf{n}=\mathbf{4 4})\end{array}$ \\
9.68 \\
3.25 \\
2.43 \\
0.57 \\
2.07 \\
0.07 \\
0.34 \\
0.95 \\
2.73 \\
\hline 12.41
\end{tabular}

Terra Firme $(\mathrm{n}=6)$

8.83

4.83

1.50

0.83

1.00

0.17

0.50

0

2.17

11.00 
are primarily birds of capoeira (second-growth), 10 primarily of terra-firme (mature upland). 9 primarily of várzea (swamp) and 1 is of an intermediate type of forest (Table 7).

\section{HEIGHTS, ANGLES AND DIAMETERS OF PERCHES}

Tables 2, 3 and 4 list the heights, angles and diameters of perches recorded for various species at Belém. In the table of heights, 0.1 includes all the records from 0 to $0.1,0.2$ includes all the records between 0.1 and 0.2 . and so on. In the table of diameters, 2 represents all records up to $2 \mathrm{~cm}, 4$ represents ali the records taken between 2 and $4 \mathrm{~cm}$, and so on; the same convention is used for angles, measured in degrees. A bird standing upright on a horizontal perch is at $0^{\circ}$, one clinging upright to a vertical one is at $90^{\circ}$, and one clinging upside down to a horizontal one is at $180^{\circ}$. (Those who have difficulty visualizing this should consider the perch to be changing in angle and not the bird).

These records include the perches used for any activity in which the bird was engaged, such as foraging, calling, preening, capturing prey, etc. Although the number of records is small except for the three main ant-followers, these tables will give an idea of perches used by different birds following army-ant raids.
The three professional antbirds (Whitebacked Fire-Eye, Black-spotted Bare-Eye and Scale-backed Antbird) tend to use thin branches near the ground when they forage actively over the sarms. Also, they constantly use vertical or horizontal perches $\left(90^{\circ}\right.$ or $\left.0^{\circ}\right)$. The first species tends to use a wide range, from 0.1 to $10 \mathrm{~m}$ up, perhaps because so many are present that some individuals, probably the lower ones in the peck order, have to forage high. Blacksijotted Bare-Eyes stay near the ground most of the time and fly to higher branches mainly when disturbed by people or other large animals. Black-spotted Bare-Eyes use vertical saplings as perches more often than do White-backed FireEyes.

Among the professional woodcreepers, the Plain-brown Woodcreeper is the only one that uses a wide range of heights, from 0.1 to more than $14 \mathrm{~m}$. The flexibility of this species in using different perch diameters as well as perch heights makes it very succesful over ants even in competition with low-perching antbirds. The Plain-brown Woodcreeper uses high perches most of the time, and comes close to the ground only when other professional antfollowers are not around. When I was netting ant-followers in front of a swarm, antbirds were caught easily in the mist nets while woodcreepers were seldom caught.

TABLE 7

Primary Habitats of Nonprofessional Ant-followers at Belém

\section{Capoeira}

Lined Forest-falcon

Squirrel Cuckoo

Smooth-billed Ani

Blue-crowned Motmot

White-fronted Nunbird

Channel-billed Toucan

Red-stained Woodpecker

Plain Xenops

Great Antshrike

Amazonian Antshrike

Spot-winged Antshrike

White-flanked Antwren

White-pearded Manakin

Great Kiskadee

Moustached Wren

Long-billed Gnatwren

Silver-beaked Tanager

Terra Firme

Buff-throated Woodcreeper

White-shouldered Antshrike

Cinereous Antshrike

Silvered Antbird

Red-headed Manakin

White-crowned Manakin

Cocoa Thrush

River Warbler

Pectoral Sparrow
Wedge-billed Woodcreeper

Spix's Woodcreeper

Plain-throated Antwren

Gray Antbird

Rufous-capped Antthrush

Black-faced Antthrush

Royal Flycatcher

Ochre-bellied Flycatcher

McConnell's Flycatcher

White-necked Thrush
Intermediate (Tangled Zones)

Bright-rumped Attila 
All three professional woodcreepers, the Plain-brown, White-chinned and Barred Wocdcreepers, use pole-sized vertical trunks ( 3 to 10 $\mathrm{cm}$ in diameter) most of the time and seldom use horizontal or diagonal branches. However, sometimes they use the under sides of horizontal branches (records of 90-180 degress).

The only tanager that is professional, the Gray-headed Tanager, uses mostly thin horizontal branches, few diagonal or vertical branches. It tends to perch from 1 to $10 \mathrm{~m}$ up, but it frequently flies near or to the ground to capture prey.

The nonprofessional woodcreepers, like professional ones, tend to use pole-sized vertical trunks at all heights; however, Wedge-billed Woodcreepers frequently climb thick trunks The nonprofessional ones differ from professional woodcreepers in searching nearby surfaces intently, pecking out prey, while all professional woodcreepers mostly look outward to distant surfaces, sallying to them for any prey that moves. Therefore, the large nonprofessional woodcreepers search nonvertical trunks at times while professional ones seldom do, being interested in a perch as a perch rather than as a source of food (Table 4).

The nonprofessional woodcreepers, antbirds, and other occasional species perch high most of the time, from 1 to $12 \mathrm{~m}$ up, and thus do not compete with professional antbirds. When the nonprofessionals do come to the ground they usually do so at one of the branches of the swarm, mainly when professional ant-followers are not present. Most of the nonprofessionals (other than woodcreepers) use thin horizontal branches and thus do not compete with professional woodcreepers. Most flycatchers, manakins, and antbirds use thin perches, while woodcreepers and oscines are not so restricted.

\section{PREY CAPTURES AT DIFFERENT HEIGHTS}

Figure 2 shows percentages of recorded prey captures at each height. As is true north of the Amazon (Oniki and Willis, in press) professional antbirds take most of the abundant prey below $0.4 \mathrm{~m}$ up. Professional woodcreepers take scattered prey at higher levels, as do Grayheaded Tanagers, but all occasionally go to the ground for prey.
Nonprofessional birds take food mostly at high levels. Antthrushes, thrushes, the River Warbler, and the Pectoral Sparrow take most of their prey on the ground but do not play an important role in taking food at ant swarms, since they do not stay long or frequently enough to obtain much food. Other species of nonprofessionals, such as manakins, woodcreepers, motmots, and flycatchers, capture prey in the zones from $2-4 \mathrm{~m}$. Above $4 \mathrm{~m}$, antbirds of all types catch little prey over ants, and woodcreepers and other species, such as nunbirds, predominate.

Professional antbirds captured 40.5 percent of the total prey, professional woodcreepers 42.6 percent and the Gray-headed Tanager 6.1 percent (Figure 2). Thus, 89.2 percent of the food is taken by professional ant-followers and only 10.8 percent is taken by nonprofessionals. Of this 89.2 percent, 79.2 percent is taken by the main ant-followers.

\section{Changes DURING THE DAY}

Table 8 shows the average numbers of records of birds per hour watched for different hours of the day at Belém. A "record" is a mention of an individual bird in my field notes. The overall activity of the birds increases toward 10:00 and then decreases into the afternoon hours. Both professionals and nonprofessionals show the same pattern of activity, except that nonprofessional activity is high between about 10:00 and 12:00, slightly after the peak of activity of professionals at 09:00 to $10: 00$. The nonprofessionals are still rather active until 16:00, wihile professionals decrease activity during the afternoon.

The White-backed Fire-Eye increases activity to a maximum at about $08: 00$ and then gradually decreases later. The Black-spotted Bare-Eye is rather active from 07:00 to $16: 00$, with somewhat less activity about midday. The Scale-backed Antbird shows a similar pattern to the Black-spotted Bare-Eye, but not enough data is available.

The Plain-brown Woodcreeper is very active in the midmorning to early afternoon, between $08: 00$ and 13:00, and fairly active later in the day. It is the most active species between 15:00 and 17:00. The Barred Woodcreeper is most active between 09:00 and 12:00. 
The Gray-headed Tanager, which competes directly with both woodcreepers and antbirds, is most active before 07:00 and between 10:00 and 14:00. Perhaps it is excluded from the swarms during the active hours from $07: 00$ to 10:00.

\section{COMPARISON WITH OTHER ANT-FOLLOWING GUILDS}

At Belém, the professional part of the antfollowing guild is composed mainly of three antbirds (one large, one medium-sized and one small), three woodcreepers (one large and two medium-sized) and one tanager (Table 1). The very large Rufous-vented Ground Cuckoo, Neomorphus geoffroyi, should be the eighth member of this guild, for it is known from the region.

The Belém guild resembles the ant-following guild on Barro Colorado Island in Panamá (Johnson, 1954) and at Finca La Selva in Costa Rica (Slud, 1960) in numbers and types of professional ant-fcllowers. On Barro Colorado

\section{BELÉM}
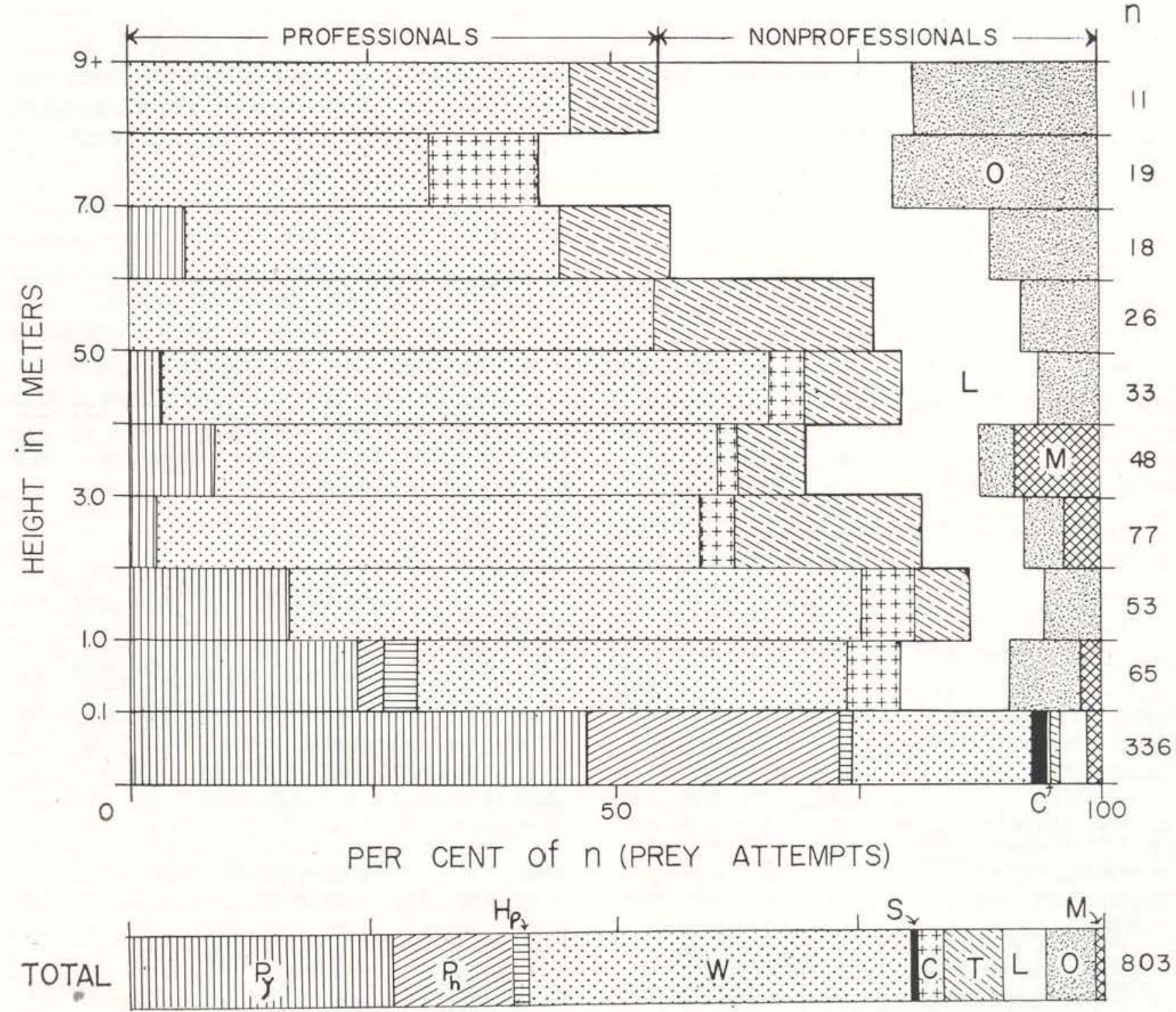

FIGURE 2 - Per cent of prey captures at each level. The total 803 includes 117 records for which height was not recorded. $\mathrm{Py}=$ Pyriglena leuconota; $\mathrm{Ph}=$ Phlegopsis nigromaculata; $\mathrm{Hp}=$ Hylophylax poecilonota; $\mathrm{W}=$ Dendrocin. cla fuliginosa; $\mathrm{S}=$ Dendrocincla merula; $\mathrm{C}=$ Dendrocolaptes certhia; $\mathrm{T}=$ Eucometis penicillata; $\mathrm{M}=$ nonprofes sional antbirds; $\mathrm{O}=$ nonprofessional woodcreepers; $\mathrm{L}=$ other nonprofessionals. 
Island (hereafter, $\mathrm{BCI}$ ) and at La Selva there were there professional antbirds: the very large Ocellated Antbird (Phaenostictus mcleannani), the medium-sized Bicolored Antbird (Gymnopithys bicolor) and the small Spotted Antbird. (Hylophylax naevioides). La Selva had also the medium-sized Bare-crowned Antbird (Gymnocichla nudiceps) and rarely the medium-sized Immaculate Antbird (Myrmeciza immaculata). There were two professional woodcreepers, the large Barred Woodcreeper and the mediumsized Plain-brow Woodcreeper, one professional cuckoo, and on $\mathrm{BCl}$ one professional tanager. Therefore, both the guilds at Belém and on $\mathrm{BCl}$ hand a large a medium, and a small antbird; a common medium-sized and a rare large woodcreeper; the fairly common Gray-headed Tanager; and (formerly) Rufous-vented GroundCuckoos. A rare medium-sized woodcreeper. Dendrocincla merula at Belém, is represented only locally near $\mathrm{BCl}$ by the somewhat similar Ruddy Woodcreeper (Dendrocincla homochroa).

At Serra ao Navio in Amapá (Oniki and Willis, in press), despite a climatic regime like that of Belém, there are four professional antbirds : the medium-sized Rufous-throated Antbird (Gymnopithys rufigula) and Black. headed Antbird (Percnostola rufifrons), the medium-small White-plumed Antbird (Pithys albifrons), and the small Scale-backed Antbird (Hylophylax poecilonota). There are also four or five professional woodcreepers, the very large Red-billed (Hylexetastes perrotti), the large B I a c k-banded Woodcreeper (Dendrocolaptes picumnus) and Barred Woodcreeper (Dendrocolaptes certhia), and the medium-sized Plainbrown Woodcreeper (Dendrocincla fuliginosa). The Gray-headed Tanager and White-chinned Woodcreeper, although reported from the region, were never observed at Serra do Navio.

TABLE 8

Records (per Hour Watched) at Different Hours of Day

Species

White-b. Fire-Eye

Black-sp. Bare-Eye

Scale-b. Antbird

Plain-b. Woodcreeper

White-ch. Woodcreeper

Barred Woodcreeper

Gray-h. Tanager

SUBTOTAL A

(Professionals)

White-f. Nunbird

Wedge-b. Woodcreeper

Buff-th. Woodcreeper

Spix's Woodcreepar

Plain-th. Antwren

Gray Antbird

Red-head. Manakin

White-b. Manakin

Moustached Wren

Long-bil. Gnatwren

Silver-bea. Tanager

Other species (26 spp.)

SUBTOTAL $\mathrm{B}_{\text {, }}$

(Nonprofessionals)

TOTAL

TOTAL RECORDS

$\begin{array}{cccc}\mathbf{5} & \mathbf{6} & \boldsymbol{7} & \mathbf{8} \\ 1.25 & 3.16 & 7.55 & 7.81 \\ 0 & 1.13 & 1.76 & 1.84 \\ 0 & 0.23 & 0.19 & 0.34 \\ 0 & 1.35 & 2.88 & 3.95 \\ 0 & 0 & 0.06 & 0.03 \\ 0 & 0 & 0 & 0.19 \\ 0 & 0.90 & 0.30 & 0.35 \\ 1.25 & 6.77 & 12.75 & 14.55\end{array}$

$\begin{array}{llll}0 & 0 & 0.06 & 0.06\end{array}$

$\begin{array}{llll}0 & 0 & 0.06 & 0.10\end{array}$

$\begin{array}{llll}0 & 0 & 0.24 & 0.16\end{array}$

$\begin{array}{llll}0 & 0 & 0 & 0.05\end{array}$

$\begin{array}{llll}0 & 0.23 & 0.06 & 0.23\end{array}$

$\begin{array}{llll}0 & 0.23 & 0.37 & 0.21\end{array}$

$\begin{array}{llll}0 & 0 & 0.13 & 0.06\end{array}$

$\begin{array}{llll}0 & 0 & 0.28 & 0.23\end{array}$

$\begin{array}{llll}0 & 0 & 0.24 & 0.39\end{array}$

$\begin{array}{llll}0 & 0 & 0.09 & 0.07\end{array}$

$\begin{array}{llll}0 & 0.68 & 0.17 & 0.22\end{array}$

$\begin{array}{llll}0 & 0.23 & 0.39 & 0.61\end{array}$

$\begin{array}{llll}0 & 1.35 & 2.09 & 2.41\end{array}$

$\begin{array}{llll}1.25 & 8.13 & 14.83 & 16.96\end{array}$

$\begin{array}{llll}1 & 36 & 690 & 1462\end{array}$
Hour of Day

$\begin{array}{ccccccccc}\mathbf{9} & \mathbf{1 0} & \mathbf{1 1} & \mathbf{1 2} & \mathbf{1 3} & \mathbf{1 4} & \mathbf{1 5} & \mathbf{1 6} & 17 \\ 7.15 & 6.88 & 5.94 & 4.85 & 3.98 & 2.54 & 2.03 & 2.71 & 2.71 \\ 1.94 & 1.98 & 1.71 & 1.21 & 1.30 & 2.02 & 1.71 & 0.71 & 0.34 \\ 0.22 & 0.18 & 0.23 & 0.24 & 0.07 & 0.26 & 0.32 & 0 & 0 \\ 5.14 & 4.35 & 3.79 & 4.48 & 3.20 & 2.35 & 3.20 & 3.29 & 2.37 \\ 0.04 & 0.02 & 0.02 & 0 & 0 & 0 & 0 & 0.12 & 0 \\ 0.31 & 0.41 & 0.48 & 0.06 & 0 & 0.20 & 0.16 & 0.12 & 0 \\ 0.78 & 1.14 & 1.36 & 1.15 & 1.04 & 0.78 & 0.23 & 0 & 0 \\ 15.58 & 14.95 & 13.53 & 12.00 & 9.59 & 8.15 & 7.64 & 6.94 & 5.42\end{array}$

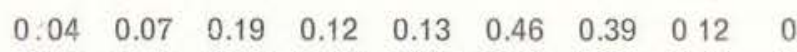

$\begin{array}{lllllllll}0.09 & 0.10 & 0.06 & 0.12 & 0.07 & 0.13 & 0.16 & 0.12 & 0\end{array}$

$\begin{array}{lllllllll}0.38 & 0.50 & 0.52 & 0.30 & 0.72 & 0.20 & 0.31 & 0.12 & 0\end{array}$

$\begin{array}{lllllllll}0.11 & 0.19 & 0.23 & 0.06 & 0.13 & 0 & 0 & 0 & 0\end{array}$

$\begin{array}{lllllllll}0.21 & 0.28 & 0.40 & 0.30 & 0.13 & 0.20 & 0 & 0 & 0\end{array}$

$\begin{array}{lllllllll}0.16 & 0.23 & 0.17 & 0 & 0.20 & 0.07 & 0.70 & 0.24 & 0\end{array}$

$\begin{array}{lllllllll}0.14 & 0.08 & 0.13 & 0.12 & 0 & 0 & 0.08 & 0.35 & 0\end{array}$

$\begin{array}{lllllllll}0.24 & 0.30 & 0.15 & 0 & 0.13 & 0.26 & 0.08 & 0.12 & 0\end{array}$

$\begin{array}{lllllllll}0.20 & 0.36 & 0.33 & 0.12 & 0.26 & 0.20 & 0.16 & 0.12 & 0\end{array}$

$\begin{array}{lllllllll}0.16 & 0.08 & 0.04 & 0.30 & 0.13 & 0 & 0 & 0 & 0.68\end{array}$

$\begin{array}{lllllllll}0.16 & 0.23 & 0.23 & 0.24 & 0.26 & 0.26 & 0.16 & 0.24 & 0\end{array}$

$\begin{array}{lllllllll}0.49 & 0.68 & 0.75 & 0.30 & 0.20 & 0.33 & 0.23 & 0 & 0\end{array}$

$\begin{array}{llllllllll}2.37 & 3.08 & 3.21 & 2.00 & 2.35 & 2.09 & 2.26 & 1.41 & 0 & 68\end{array}$

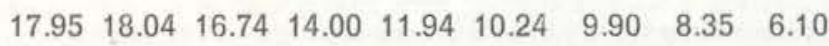

$\begin{array}{lllllllll}1726 & 1602 & 803 & 231 & 183 & 157 & 127 & 71 & 18\end{array}$ 


\section{DISCUSSION}

Table 1 and the following tables show some foraging differences between the professional ant-followers at Belém. Probably these differences help them forage together, although there is some overlap and some fighting.

The three professional antbirds differ in weight, but differ little in bill length. Sizes of prey are thus not likely to be very different. The antbirds differ somewhat in habitat. Otherwise they differ mainly in that the large. dominant Bare-Eye takes the central and low zones over the ants and there waits patiently for nearby prey; the medium-sized, subdominant and numerous Fire-Eyes hop and peck or sally around and above any Bare-Eyes present; and the rare, small and subordinate Scale-backed Antbirds wait patiently or move about on the outskirts of swarms.

The three professional woodcreepers differ more in bill length than do antbirds. The uncommon, large Barred Woodcreeper takes large prey, mostly high above the groun. The common, medium-sized Plain-brown Woodcreeper takes many sizes of prey at many places, but mainly high above the ants. It moves low over ants mainly when antbirds are not present, but generally also uses larger perches than they use. The rare, medium-sized White-chinned Woodcreeper forages low over ants, and differs from antbirds mainly in using vertical large perches.

The Gray-headed Tanager is a generalized species that in this region often forages away from ants, joining wandering mixed flocks in the varzea. It moves in low over ants mainly where antbirds are locally absent. Much of its food is taken high above ants, in competition with Plain-brown Woodcreepers. However, the tanager generally uses horizontal slender perches and thus must tend to see different prey from the woodcreeper, which usually takes vertical large perches.

Nonprofessional woodcreepers ove rlap strongly with professional ones in types of per. ches." However, the nonprofessional woodcreepers tend to peer at or in the perching surface or a nearby one, and peck at or extract prey while professional ant-followers tend to use a perch as a site from which they look out to distant surfaces for prey.

Nonprofessional antbirds overlap strongly with professional ones in types of perches, and consequently differ from all woodcreepers. However, most nonprofessional antbirds forage moderately high (2-5 $\mathrm{m}$ up) or wander at the periphery of swarms. Therefore, they also overlap little with professional antbirds.

Other nonprofessional species are mainly large birds that take horizontal large or mediumsized perches fairly high above ants, or small species that wander high or peripherally. The former differ from woodcreepers in perch type. and the latter differ from antbirds in staying high or peripherally and in following ants infrequently.

At Belém and in most other regions, medium-sized antbirds like Fire-Eyes are more numerous at swarms than are large or small ones. Perhaps this is because the average and most abundant size of food tends to be small or medium near the ground. Professional antbirds at Belem differ little in bill length, although they differ greatly in body size Bill length probably reflects the size of prey, or at least the average maximum size of prey, in antbirds (Oniki and Willis, in press). By contrast, body size differences in antbirds seem to be related to maintaining dominance and thus keeping a central or near-central zone over ants. Small antbirds must perhaps depend on uncommon very small prey or are too low in the interspecific peck order to do well, even though they sometimes do well in dry-forested regions where there are few larger antbirds (cf. Slud, 1964, p. 221, for Spotted Antbirds, Hylophylax naevioides, in Costa Rica). Large antbirds, though dominant, probably find little food unless they have small bills and take small prey, in which case they use much energy per unit of intake. They must then stay near the swarm center, where ants flush much prey; but there is less room centrally than peripherally. Thus, they cannot become common birds.

Antbirds are flexible in kinds of perches taken and are faster in moving about and in getting food near the ground than are woodcreepers, which are clumsy on the ground and have to turn around from their vertical thick 
perches to fly or dart for prey. However, woodcreepers are more flexible about foraging levels and in long-distance sallying. Most of these woodcreepers can obtain food by hovering under leaves and capturing prey hidden there, underneath bark, on trunks, in crevices, on the ground, or inside curled dried leaves at many heights, while antbirds obtain most of their food on the ground or underneath low leaves on saplings. Also, ant-following antbirds wander through the forest looking for new swarming colonies and seldom join wandering flocks of birds to obtain food away from ants, while such woodcreepers as Plain-brown, Buff-throated and Barred Woodcreepers join these flocks frequently (Oniki, 1971).

\section{ACKNOWLEDGEMENTS}

I gratefully acknowledge the hospitality of IPEAN personnel and the coordinators of the APEG Program at Belém, D. Dias and João $M$. Pires.

This study was supported by the programs of the APEG through IPEAN, and by a fellowship from the Conselho Nacional de Pesquisas of Brazil. Writing was completed while I held fellowships from the Organization of American States, the University of Kansas Museum of Natural History, and an Eliza Matheson Innes Memorial Scholarship.

The present paper is based on a M. A. thesis presented to the Department of Systematics and Ecology of the University of Kansas. I am grateful to Drs. Philip S. Humphrey, Edwin O. Willis and Paul Slud, who patiently directed and gave helpful advice for field work and for the manuscript. Robert M. Mengel also helped with the latter and in other ways. David M. Niles was also kind enough to read this paper.

James Karr and Thomas E. Lovejoy kindly provided me with weights of Panamanian and Brazilian birds respectively. Richard Zusi and Kenneth Parkes, curators of birds at the U. S. National Museum and the Carnegie Museum, provided bird specimens for study. In addition, I am most grateful to Fernando C. Novaes curator of birds at the Museum Paraense "Emilio Goeldi", who provided bird specimens for study.

\section{SUMÁRIO}

1. Nas matas das Reservas Aurá e Mocambo de Belém, Brasil, a associação de aves que seguem persistentemente as formigas de correição inclue sete espécies importantes. Ás aves consideradas como seguidoras professionais de correição pelo fato de elas obterem mais de $50 \%$ de sua alimentação junto às formigas são: três formicariideos, um grande (Phlegopsis nigromaculata), um médio (Pyriglena leuconota) e um pequeno (Hylophylax poecilonota); três dendrocolaptídeos, um grande (Dendrocolaptes certhia), e dois médios (Dendrocincla fuliginosa e $\mathbf{n}$. merula); e um tanagrídeo (Eucometis penicillata). Embora relatado na área, um cuculídeo (Neomorphus geoffroyi) näo foi observado em Belém.

2. Estas sete espécies de aves seguiam as formigas de correição, Eciton burchelli, em três tipos de mata: capoeira, terra firme e várzea. Algumas espécies eram mais comuns em um dos tipos de habitat, mas elas frequentemente moviam com as formigas de um habitat para outro. Trinta e sete espé. cies de aves ocasionais ou amadoras também seguiram as formigas, principalmente em capoeira. Muitas espécies amadoras, que não seguem persistentemente as formigas de correição, eram restritas à um tipo de habitat.

3. Diferenças em tamanho entre as três formicariideos profissionais não são refletidos em comprimento de bico, e as diferenças principais parecem ser em habitat e em exclusão da ave menor e mais rápida em movimentos por dominância pelas aves mai. ores e mais lentas em movimentos. Os dendrocolaptideos dividem-se em tamanho e comprimento de bico ou em captura de alimentos próximo do chão cu no alto.

4. Os formicariideos profissionais em geral capturam seus alimentos no chāo ou próximo ao chão acima das correiçōes das formigas, enquanto os dendrocolaptídeos profissionais capturam seus alimentos principalmente mais acima e vêm próximo ao chão sòmente quando os formicariideos não estão presentes ou estão nas vizinhanças. Dendrucincla me. rula, um dendrocolaptídeo de tamanho médio cap. tura seus alimentos próximo ao chão, mas tende a pousar em troncos grandes ao invés de troncos pequenos usados pelos formicarí́deos. O tanagrídeo, Eucometis penicillata, pousa em ramos grossos ou finos mas tende a ficar nas florestas de várzea ou seguir outros bandos de aves longe das formigas de correição.

5. As aves amadoras em seguir as formigas de correição capturam alimentos geralmente em alturas acima de $2 \mathrm{~m}$, de maneira que superpõem aos hábitos das aves profissionais. Muitos aves amadoras em seguir as formigas têm a tendência de pousar em ramos finos, horizontais enquanto capturam alimentos e portanto não interferem grandemente com os hábitos 
dos dendrocolaptídeos profissionais que preferem grandes troncos verticais. Os dendrocolaptídeos não profissionais geralmente investigam as superfícies dos troncos em que sobem enquanto os profissionais obse'vam cuidadosamente superfícies adjacentes aos troncos em que estão pousados.

\section{LITERATURE CITED}

Beebe, M. B. \& Beebe, W. C.

1910 - Our Search for a wilderness. Henry Holt and Co., New York, 408 p.

CHAPIN, T. P.

1932 - The birds of the Belgian Congo,. Part I. Bull. Amer. Mus. Nat. Hist., 65:1-756 p.

Ducke, A. \& BLACK, G. A.

1954 - Notas sôbre a fitogeografia da Amazônia Brasileira. Bol. Téc. do Instituto Agronômico do Norte, no $29: 1-62 \mathrm{p}$.

JOHNSON, R. A.

1954 - The behavior of birds attending army ant raids on Barro Colorado Island, Panamá $\mathrm{Ca}^{-}$ nal Zone. Proc. Linn. Soc., N. Y., 64-65: 41-70.

KuHLManN, E.

1959 - Tipo de vegetação, pp. 112-127. In : Grande Região Norte, Bibl. Geg. Brasil, IBGE, vol. I, série $A$, xxiv -422 p.

MEERWAKTH, H. VAN

1940 - Eine zoologische Forschungsreise nach dem Rio Acará in Staate Pará (Brasilien). Globus, 86 : 289-296, 309-315.

Meyer de SChAuensee, R.

1966 - The species of birds of South America and their distribution. Narberth, Pennsylvania, Livingston Publ. Co., 577 p.

Novaes, F. C.

1970 - Distribuição ecológica e abundância das aves em um trecho da mata do baixo Rio Guamá (Estado do Pará). Bul. Mus. Goeldi, 71: 1 -54.

ONIKI, Y.

1971 - Wandering interspecific flocks in relation to anti-following birds at Belém, Brazil. Condor, 73(3) : $372-374$.
ONIKI, Y. \& WILLIS, E. O.

1972 - Studies of ant-following birds north of the Eastern Amazon. Acta Amazonica.

RETTENMEYER, C. W.

1963 - Behavioral studies of army ants. Univ. Kans. Sci. Bull., $44: 281.465$.

RоOT, R. B.

1967 - The niche exploitation pattern of the Bluegray Gnatcatcher. Ecol. Monog., 37: 317-350.

SCHNEIRLA, T. C.

1957 - A comparison of species and genera in the ant subfamily Dorylinae with respect to functional pattern. Insectes Sociaux, 4: 259-298.

SKUTCH, A. F.

1969 - Life histories of Central American birds. III. Families Cotingidae, Pipridae, Formicariidae, Furnariidae, Dendrocolaptidae, and Picidae. Pacific Coast Avifauna, n? 35, 580 p.

SLUd, $\mathrm{P}$,

1960 - The birds of finca "La Selva", Costa Rica: a tropical wet forest locality. Bull. Amer. Mus. Nat. Hist., 121: 49-148.

1964 - The birds of Costa Rica : Distribution and ecology. Bull. Amer. Mus. Nat. Hist., $128: 1-430$.

SNow, D. W.

1962 - A field study of the Black and White Manakin, Manacus manacus, in Trinidad. Zoologica, 47 : 65-104.

WILLIS, E. O.

1960 - A field study of the foraging behavior of two species of ant-tanagers. Auk, 77:150-170.

$1966 \mathrm{a}$ - The role of migrant birds at swarms of army ants. Living Bird, 5: 187-231

1966b - Interspecific competition and the foraging behavior of Plain-brown Woodcreepers. Ecology, 47: 667-672.

1967 - The behavior of Bicolored Antbirds. Univ. Calif. Publ. Zool., 79: 132 p.

1968a - Taxonomy and behavior of Pale-faced Antbirds. $A u k, 85: 253-264$.

$1968 \mathrm{~b}$ - Studies of the behavior of Lunulated and Salvin's Antbirds. Condor, 70: 128-148.

1969 - On the behavior of five species of Rhegma. torhina, ant-following antbirds of the Amazon basin. Wilson Bull., 81 : 363-395. 